\title{
Denitrification likely catalyzed by endobionts in an allogromiid foraminifer
}

\author{
Joan M Bernhard ${ }^{1}$, Virginia P Edgcomb ${ }^{1}$, Karen L Casciotti ${ }^{2,4}$, Matthew R McIlvin ${ }^{2}$ and \\ David J Beaudoin ${ }^{3}$ \\ ${ }^{1}$ Geology and Geophysics Department, Woods Hole Oceanographic Institution, Woods Hole, MA, USA; \\ ${ }^{2}$ Marine Chemistry and Geochemistry Department, Woods Hole Oceanographic Institution, Woods Hole, \\ MA, USA and ${ }^{3}$ Biology Department, Woods Hole Oceanographic Institution, Woods Hole, MA, USA
}

\begin{abstract}
Nitrogen can be a limiting macronutrient for carbon uptake by the marine biosphere. The process of denitrification (conversion of nitrate to gaseous compounds, including $\mathrm{N}_{2}$ (nitrogen gas)) removes bioavailable nitrogen, particularly in marine sediments, making it a key factor in the marine nitrogen budget. Benthic foraminifera reportedly perform complete denitrification, a process previously considered nearly exclusively performed by bacteria and archaea. If the ability to denitrify is widespread among these diverse and abundant protists, a paradigm shift is required for biogeochemistry and marine microbial ecology. However, to date, the mechanisms of foraminiferal denitrification are unclear, and it is possible that the ability to perform complete denitrification is because of the symbiont metabolism in some foraminiferal species. Using sequence analysis and GeneFISH, we show that for a symbiont-bearing foraminifer, the potential for denitrification resides in the endobionts. Results also identify the endobionts as denitrifying pseudomonads and show that the allogromiid accumulates nitrate intracellularly, presumably for use in denitrification. Endobionts have been observed within many foraminiferal species, and in the case of associations with denitrifying bacteria, may provide fitness for survival in anoxic conditions. These associations may have been a driving force for early foraminiferal diversification, which is thought to have occurred in the Neoproterozoic era when anoxia was widespread.
\end{abstract}

The ISME Journal (2012) 6, 951-960; doi:10.1038/ismej.2011.171; published online 1 December 2011

Subject Category: microbe-microbe and microbe-host interactions

Keywords: denitrification; GeneFISH; nirK; marine sediment; Pseudomonas; symbiosis

\section{Introduction}

Over the past decade, our understanding of the nitrogen cycle has changed drastically (Francis et al., 2007) with the discovery of anaerobic ammonium oxidation (anammox, Dalsgaard et al., 2005), archaeal ammonia oxidation (Könneke et al., 2005) and the ability of foraminiferal eukaryotes to perform complete denitrification (Risgaard-Petersen et al., 2006). The first report of benthic foraminifera having the ability to perform complete denitrification was exciting because denitrification was thought to be a process facilitated only by prokaryotes and some fungi. Additional studies suggest that the ability of foraminifera to denitrify is widespread (Høgslund et al., 2008; Piña-Ochoa et al., 2010). Dozens of

Correspondence: JM Bernhard, Geology and Geophysics Department, Woods Hole Oceanographic Institution, Woods Hole, MA 02543, USA.

E-mail: jbernhard@whoi.edu

${ }^{4}$ Current address: Stanford University, Department of Environmental Earth System Science, Stanford, CA 94305, USA.

Received 15 August 2011; revised 30 September 2011; accepted 11 October 2011; published online 1 December 2011 foraminiferal species from a wide taxonomic range have been shown to store nitrate, and of the ten foraminiferal species analyzed for denitrification rates, nine perform complete denitrification. However, our understanding of the mechanisms of denitrification in these protists is incomplete.

We addressed uncertainties about foraminiferal denitrification in a symbiont-bearing allogromiid foraminifer. Although allogromiid foraminifera, which are tectinous and unilocular, differ in morphology and test (shell) chemistry from the multilocular calcareous Globobulimina pseudospinescens, which was the first foraminiferal species determined to perform denitrification (RisgaardPetersen et al., 2006), the species live in similar habitats. The SBB (Santa Barbara Basin) allogromiid lives in relatively high abundance in sediments of the deepest part of the SBB (Bernhard et al., 2006), and is the only allogromiid common in this part of the basin where denitrification might be expected because bottom-water oxygen concentrations in this area can be very low (typically $<2 \mu \mathrm{M}$ ) (Bernhard et al., 1997) or undetectable (Bernhard et al., 2006). At times, sulfide concentrations can be considerable 
in this area (Bernhard et al., 2003). The species was selected because of a number of its attributes, including its ecology, abundant endobionts and copious large cytoplasmic vacuoles (Bernhard et al., 2006) (Figure 1). The abundant endobionts of this SBB allogromiid appear to be one morphotype in the many specimens examined previously (Bernhard et al., 2006). The copious large cytoplasmic vacuoles in this allogromiid are easily observed, and were noted in both fixed and live specimens in a prior cell-ultrastructural study (Bernhard et al., 2006). Although this foraminiferal species is not formally described, it is morphologically distinct and its small subunit ribosomal RNA gene sequence (GenBank accession number AY818728) was found to group consistently in the basal foraminiferal lineage 'Clade L' (Bernhard et al., 2006).

In the earlier study of this SBB allogromiid, the identity of the endobiont was unknown but was hypothesized to be a sulfur-oxidizing bacterium (Bernhard et al., 2006). The reports of denitrification in foraminifera spawned two new hypotheses, however: (1) that the allogromiid's large cytoplasmic vacuoles contained nitrate and (2) that the endobionts were denitrifiers. Using a variety of geochemical and molecular approaches, we address these hypotheses and consider the results with respect to chemocline biogeochemistry and ecology, as well as early foraminiferal diversification.

\section{Materials and methods}

\section{Sample collection}

Samples were collected from water depths of 580$590 \mathrm{~m}$ in SBB, which is a silled basin with restricted water circulation located off Southern California, USA (centered on $34^{\circ} 13.5 \mathrm{~N}, 120^{\circ} 02^{\prime} \mathrm{W}$ (Reimers et al., 1990; Reimers et al., 1996). Sediments were collected on five occasions (9/07, 6/08, 10/08, 6/09 and 4/10) with a Soutar boxcorer (Ocean Instruments, San Diego, CA, USA), from which various samples were obtained. Those intended as sources for live material were placed along with bottom water in tightly sealed high-density polyethylene bottles, kept chilled and transported to our lab where they were maintained at $7^{\circ} \mathrm{C}$, which is near ambient temperature.

\section{Nitrate content and isotopic composition}

To determine intracellular nitrate concentrations, live specimens were isolated from sediments by gently sieving over a $90-\mu \mathrm{m}$ screen using chilled bottom water as soon as possible (within a few days) after returning to the laboratory, rinsed twice in $0.2 \mu \mathrm{m}$-filter, nitrate-free seawater, measured for length and diameter using an ocular micrometer mounted on a Nikon SMZ 2B stereomicroscope (Nikon, New York, NY, USA), and individually air dried in $0.2 \mathrm{ml}$ acid-cleaned polypropylene tubes. Nitrate content and isotopic composition were measured
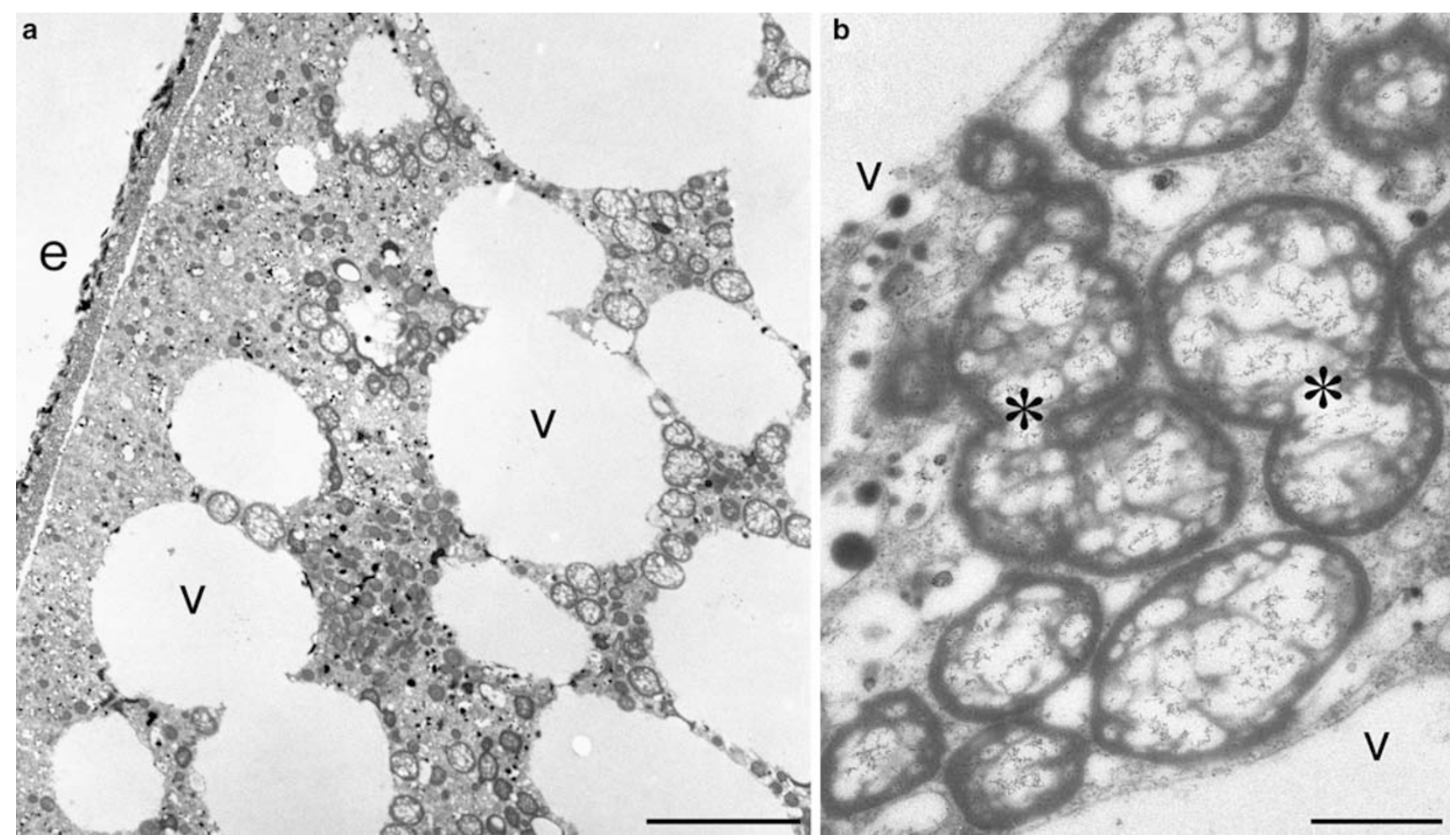

Figure 1 Transmission electron microscopy micrographs of the SBB allogromiid. (a) Low magnification view showing abundant vacuoles (v) in the endoplasm vs ectoplasm; e, environment outside foraminifer. (b) View of coccoid endobionts showing their tendency to form short chains ${ }^{*}$ ). Scales: $a=5 \mu \mathrm{m} ; b=1 \mu \mathrm{m}$. 
using isotope ratio mass spectrometry with the denitrifier method (Sigman et al., 2001), which relies on conversion of $\mathrm{NO}_{3}^{-}$(nitrate) to $\mathrm{N}_{2} \mathrm{O}$ (nitrous oxide) and sensitive detection of $\mathrm{N}_{2} \mathrm{O}$ via isotope ratio mass spectrometry. Air-dried individuals were dissolved in $100 \mu \mathrm{l}$ acetic acid, and replicate $50 \mu \mathrm{l}$ aliquots were analyzed for nitrate content against low-level (0.05-1.0 nmol) nitrate standards using the peak area of the major ion beam $(\mathrm{m} / \mathrm{z}=44)$. Intracellular nitrate concentrations were determined using recorded dimensions and volume calculations for a cylinder prolate spheroid $\left(\pi\left[\frac{1}{2} \mathrm{~W}\right]^{2} \mathrm{~L}\right.$, where $\mathrm{W}=$ width and $\mathrm{L}=$ length). When nitrate content was sufficient $(>0.5 \mathrm{nmol})$, the $\delta^{15} \mathrm{~N}$ of the nitrate $\left(\delta^{15} \mathrm{~N}_{\mathrm{NO} 3}=\left(\left({ }^{15} \mathrm{~N} /{ }^{14} \mathrm{~N}\right)_{\mathrm{NO} 3} /\left({ }^{15} \mathrm{~N} /{ }^{14} \mathrm{~N}\right)_{\mathrm{AIR}}-1\right) \times 1000\right)$ was determined for the individual. $\delta^{15} \mathrm{~N}_{\mathrm{NO} 3}$ was normalized to the AIR reference scale by the analysis of nitrate reference materials USGS32, USGS34 and USGS35 at 0.1-1.0 nmol levels.

DNA extraction, PCR amplification, alignment and phylogenetic analysis

Nucleic acids were extracted from individual allogromiids, obtained from sediments by picking cells under a dissecting microscope, from sediments in a petridish resting on ice with a pulled Pasteur pipette. Picked cells were washed briefly by transferring them three times into sterile seawater to remove most loosely attached bacteria from the test surface, and DNA was extracted using either a standard cetyl trimethylammonium bromide extraction protocol (Winnepenninckx et al., 1993) or the Qiagen DNeasy Plant DNA Extraction kit (Qiagen, Valencia, CA, USA). There were 10-35 individuals pooled for each extraction method. Amplification of 16S rRNA gene fragments were performed using each of these DNA extracts using combinations of the bacterial primers $8 \mathrm{~F}, 357 \mathrm{~F}, 1542 \mathrm{R}$ (Lane, 1991) and $341 \mathrm{~F}$ (Muyzer et al., 1993), the universal reverse primer 1492R (Longnecker and Reysenbach, 2001) and the archaeal primer $1100 \mathrm{~F}$ (Reysenbach and Pace, 1994). PCR conditions were: $95{ }^{\circ} \mathrm{C}$ for $5 \mathrm{~min}$ followed by 35 cycles of $95^{\circ} \mathrm{C}$ for $1 \mathrm{~min}, 45^{\circ} \mathrm{C}$ for $1 \mathrm{~min}$ and $72^{\circ} \mathrm{C}$ for $90 \mathrm{~s}$, with a final incubation of $72{ }^{\circ} \mathrm{C}$ for $7 \mathrm{~min}$ for primer sets $357 \mathrm{~F} / 1542 \mathrm{R}, 1100 \mathrm{~F} /$ 1492R, 8F/1492R and 8F/1542R. PCR conditions for primer set $341 \mathrm{~F} / 1492 \mathrm{R}$ were $95{ }^{\circ} \mathrm{C}$ for $5 \mathrm{~min}$ followed by 35 cycles at $95{ }^{\circ} \mathrm{C}$ for $1 \mathrm{~min}, 50{ }^{\circ} \mathrm{C}$ for $1 \mathrm{~min}$ and $72{ }^{\circ} \mathrm{C}$ for $1 \mathrm{~min}$ followed by $72^{\circ} \mathrm{C}$ for $10 \mathrm{~min}$.

PCR amplifications of the dissimilatory nitrite reductase genes nirK and nirS were attempted using extracted DNA and published primers: Cunir3/ Cunir4 (Casciotti and Ward, 2001) and FlaCu/R3Cu (Hallin and Lindgren, 1999), or nirS1F/nirS6R (Braker et al., 1998) and cd3aF/R3cd (Michotey et al., 2000; Throback et al., 2004), respectively. Touchdown PCR was used with an annealing temperature beginning at $50{ }^{\circ} \mathrm{C}$ and decreasing by $-0.5{ }^{\circ} \mathrm{C}$ per cycle for the initial 10 cycles, followed by 30 cycles at an annealing temperature of $45^{\circ} \mathrm{C}$. The positive controls were Alcaligenes faecalis for
nirK and Pseudomonas stutzeri for nirS. Allogromiid specimens were also screened for sulfur oxidation and sulfate reduction genes $\operatorname{sox} B$ and $d \operatorname{sr} A B$, respectively, with Thiomicrospira species strain L-12 and Desulfovibrio vulgaris as positive controls, respectively, using established primers and protocols (Petri et al., 2001). Dissimilatory (bi)sulfite gene amplifications were run using the DSR1Fmix and DSR4Rmix primer sets (Loy et al., 2004).

PCR products from all positive amplifications were gel-purified using the Qiaquick Gel Extraction Kit (Qiagen) and cloned into the pCR4 vector in the TOPO TA cloning kit (Invitrogen, Carlsbad, CA, USA), according to the manufacturer's instructions (for 357F/1492R, four separate amplification products were pooled before cloning). Selected clones (74 from 357F/1542R and 16-24 clones from all other primer pairs) were sequenced using an Applied Biosystems 3730XL capillary sequencer. Sequences were then edited and assembled into contigs using Sequencher (Gene Codes Corporation, Ann Arbor, MI, USA). Chimeric sequences were removed from further analyses by visual inspection and the CHECK_CHIMERA program (Cole et al., 2003).

Clone sequences were aligned using the autoaligner function within the software ARB (Ludwig et al., 2004) (http://www.arb-home.de) using the SILVA Reference database, and then the alignment was manually corrected using secondary structure information. Only reliably aligned sites were included in subsequent phylogenetic analyses. Bootstrapping and determination of the best estimate of the maximum likelihood tree topology were conducted with the Rapid Bootstrapping algorithm of RAxML (1000 bootstrap replicates) version 7.0, under the GTR (general time reversible) + I model running on the CIPRES portal (Stamatakis, 2006; Stamatakis et al., 2008) (http://www.phylo.org).

\section{FISH (fluorescent in situ hybridization) and CARD (catalyzed reporter deposition)-FISH}

On the ship, sediments were preserved in $2.0 \%$ paraformaldehyde for $1 \mathrm{~h}$, rinsed three times in phosphate-buffered saline (PBS), and then stored in PBS/ethanol (1:1) for later analysis by FISH. Specimens for FISH were hand picked under the dissecting microscope, washed briefly by transferring them three times into sterile seawater to remove most loosely attached bacteria from the test surface, and transferred to a $0.2-\mu \mathrm{m}$ pore size, $25-\mathrm{mm}$ Isopore GTTP filter (Millipore, Billerica, MA, USA). The filters were subsequently overlaid with $0.2 \%(\mathrm{w} / \mathrm{V})$ Metaphor agarose (Cambrex Bioscience Rockland Inc., Charles City, IA, USA) at $37^{\circ} \mathrm{C}$ and then dried at $50{ }^{\circ} \mathrm{C}$. FISH protocols followed those published in Pernthaler et al. (2001), and CARD-FISH protocols followed Edgcomb et al. (2010), as modified from Pernthaler et al. (2002). The only variation to the CARD-FISH protocol was the use of a multistep permeabilization routine when targeting intact allogromiid cells that incorporated a 1-h incubation at 
$37^{\circ} \mathrm{C}$ in lysozyme solution $\left(10 \mathrm{mg} \mathrm{ml}^{-1}\right.$ final concentration), followed by a wash in $50 \mathrm{ml}$ of sterile PBS, a 1-h incubation in ProteinaseK $(50 \mu \mathrm{l}$ of $1064 \mathrm{U} \mathrm{ml}^{-1}$ in $10 \mathrm{ml}$ Tris EDTA), deactivation in $0.01 \mathrm{M} \mathrm{HCl}$ for $20 \mathrm{~min}$, a wash in $50 \mathrm{ml}$ sterile PBS, a 30 -min incubation in TritonX $(0.5 \%$ in PBS), and a final wash in $50 \mathrm{ml} \mathrm{PBS}, 50 \mathrm{ml}$ of MilliQ- $\mathrm{H}_{2} \mathrm{O}$ and $50 \mathrm{ml}$ 200-proof ethanol. The probes used include EUB338 I-III (Amann et al., 1990; Daims et al., 1999), NON338 (Wallner et al., 1993), Arch915 (Stahl and Amann, 1991), DELTA495a, b and $c$, and the corresponding competitor probes for each, cDELTA495a, b and c (Lucker et al., 2007), BET42a (Manz et al., 1992), BET42a competitor (Yeates et al., 2003), Gam42a (Manz et al., 1992), Gam42a competitor (Yeates et al., 2003) and a general Pseudomonas probe PS1284 (Gunasekera et al., 2003). All probe hybridizations were conducted with $35 \%$ formamide and $0.080 \mathrm{M} \mathrm{NaCl}$; all were conducted at $46{ }^{\circ} \mathrm{C}$ and washed at $48^{\circ} \mathrm{C}$ following published optimized protocols, confirmed in our laboratory with positive control pure cultures ( $\delta$-, $\beta$ - and $\gamma$-proteobacteria) for each probe. For regular FISH hybridization studies targeting the allogromiid endobionts, the hosts were lysed to expose endobionts by vortexing for $15 \mathrm{~s}$ before depositing lysate on filters. All filters were mounted in Citifluor/Vectashield mounting solution (5.5 parts Citifluor, 1 part Vectashield and 0.5 parts $1 \times \mathrm{PBS}$ ) with $1 \mu \mathrm{g} \mathrm{ml}^{-1}$ final concentration of 4',6-diamidino-2-phenylindole (DAPI), and stored at $-20{ }^{\circ} \mathrm{C}$ until microscopy was performed, as described below under the GeneFISH protocol.

\section{GeneFISH}

GeneFISH uses multiple digoxigenin-labeled polynucleotide probes to target genes, followed by the binding of horseradish peroxidase-conjugated antibodies and CARD to amplify and visualize the signal (Moraru et al., 2010). Published protocols were followed, except that a FISH probe (vs a CARDFISH probe) was used for the 16S rRNA gene. For our application, the FISH probe targeting the ribosomal RNA gene was the general Pseudomonas probe (Gunasekera et al., 2003), and the $437 \mathrm{bp}$ digoxigenin-labeled probe targeting the nirK gene was generated using primers specific to the allogromiid nirK sequence. The forward primer was FLaCu 5'-ATCATGGTSCTGCCGCG-3'; the reverse was R3Cu 5'-GCCTCGATCAGRTTGTGGTT-3' (Hallin and Lindgren, 1999). The construction of this digoxigenin-labeled probe used the Roche PCR DIG Probe Synthesis Kit (Roche Diagnostics, Basel, Switzerland) and $25 \mathrm{pg}$ of template DNA. PCR cycling consisted of $1 \mathrm{~min}$ denaturation at $95^{\circ} \mathrm{C}$, followed by 30 cycles of $95^{\circ} \mathrm{C}$ for $1 \mathrm{~min}, 45^{\circ} \mathrm{C}$ for $1 \mathrm{~min}$ and $72^{\circ} \mathrm{C}$ for $90 \mathrm{~s}$, followed by a final single cycle of $72{ }^{\circ} \mathrm{C}$ for $7 \mathrm{~min}$. It was not possible to test this probe on a separate positive control organism because, by definition, in this protocol the probe is unique to this particular nirK sequence, and would not be expected to hybridize optimally to another slightly different nirK sequence. With GeneFISH, Moraru et al. (2010) reported that background fluorescence can come from false signals that are as bright as the true gene signal and from background fluorescence that is much weaker than the gene signal, such as that generated by tissue autofluorescence. As discussed at great length in Moraru et al. (2010), with the current GeneFISH protocol it is not yet possible to completely eliminate false positive hybridization signal of the first type described above, which can occur at random on both host material and on bacterial cells. A hybridization result is judged to be positive, therefore, when false positives (scored by hybridization of the gene probe to DNAse-treated samples) are significantly outnumbered by positives (hybridization of the gene probe to samples not treated with DNAse) (Moraru et al., 2010). Gene-specific hybridization is also assessed against a simultaneously hybridized 16S rRNA probe; in this case the Pseudomonas-specific 16S rRNA probe. By applying the gene probe during the GeneFISH protocol at a concentration of $25 \mathrm{pg}^{-1}$ and using a 22-h hybridization, acceptable percentages of false positive signals (1-4\%) and hybridization efficiencies (50-65\%) were obtained. These results were repeated with a minimum of 20 allogromiid smear preparations. Although disruptive of the allogromiid cell organization, lysing individuals and depositing several spots of the lysate on each filter reduced interference from background and the three-dimensional shape of the host, making it easier to distinguish the colocation of 16S rRNA and nirK hybridization than with intact allogromiids. As noted in Moraru et al. (2010), hybridization efficiency for the gene probe is often $\sim 45 \%$, and false positives $\sim 4-7 \%$. GeneFISH images were collected using a Zeiss Axioplan 2 epifluorescence microscope (Zeiss, Thornwood, NY, USA) equipped with a Zeiss AxioCam camera and $\times 20$ to $\times 100$ objectives.

\section{Results}

\section{Nitrate}

Intracellular nitrate contents of the SBB allogromiid foraminifer were variable. Some individuals had high $\mathrm{NO}_{3}^{-}$contents (up to $1172 \mathrm{pmol}$ per specimen; mean $=570 \pm 354$ pmol per individual, $n=10$ ) whereas others contained no $\mathrm{NO}_{3}^{-}(n=17)$. When normalized per unit volume, nitrate concentrations varied substantially $\left(70 \pm 49 \mathrm{mmol}^{-1} ; n=10\right)$, but were as high as $165 \mathrm{mmol}^{-1}$ in one individual. In those individuals with sufficient $\mathrm{NO}_{3}^{-}$to measure $\delta^{15} \mathrm{~N}_{\mathrm{NO} 3}$, specimens had consistently high $\delta^{15} \mathrm{~N}_{\mathrm{NO} 3}$ values $(17.6 \pm 0.2 \% ; n=7)$.

\section{$16 S$ rRNA sequencing}

All bacterial primer pairs tested (see Materials and methods) produced a positive PCR amplification from the SBB allogromiid. Archaeal 16S rRNA genes 


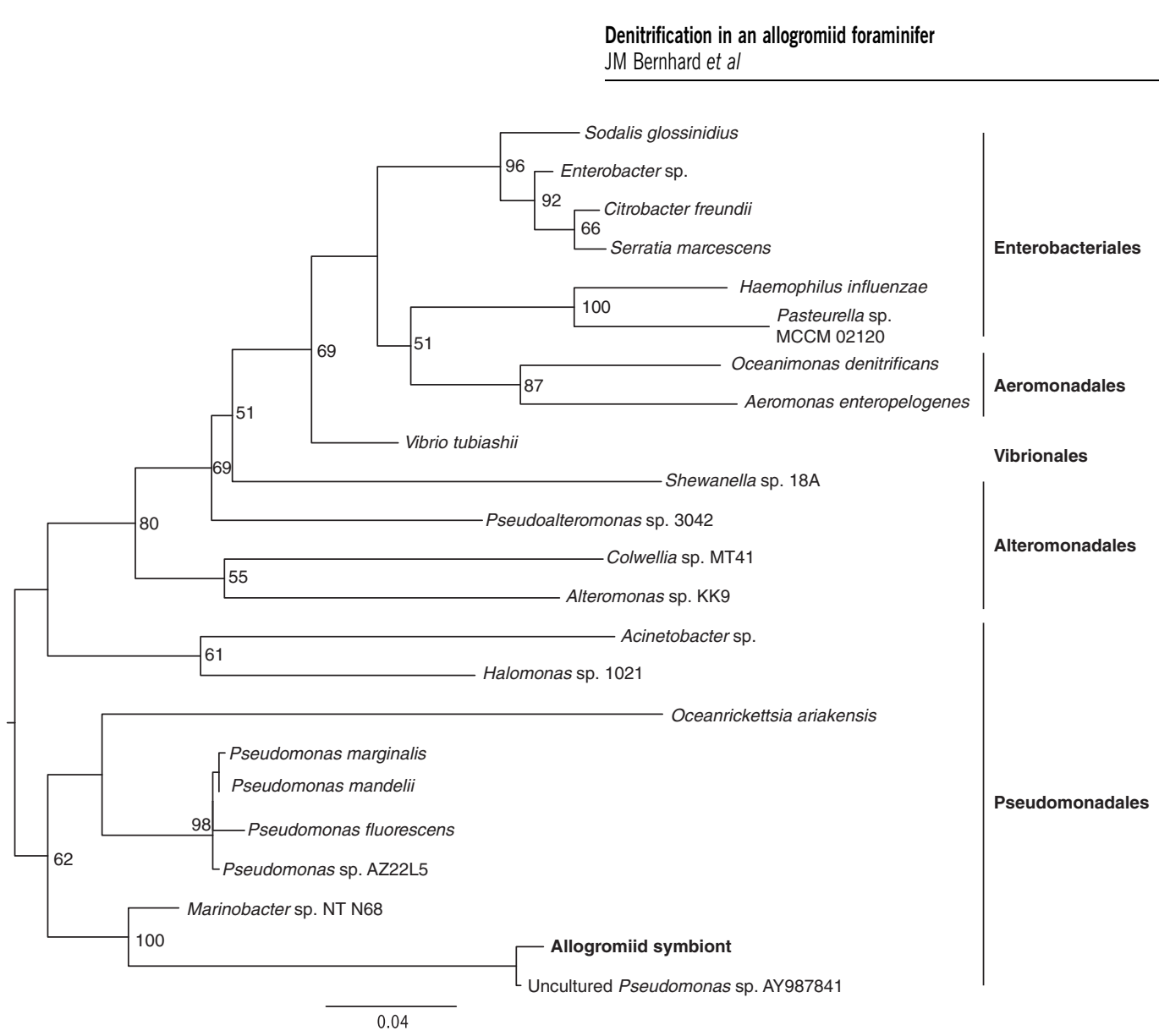

Figure 2 Phylogenetic analysis of the 16S rRNA gene from the endobiont of SBB allogromiid showing its placement within $\gamma$-proteobacteria. Maximum likelihood tree is based on an alignment of 1400 nucleotides. Scale is given as substitutions per site. See Materials and methods for detail.

were not detected by PCR. The bacterial $16 \mathrm{~S}$ rRNA gene clone libraries included multiple taxonomic groups, including $\delta$-proteobacteria, $\beta$-proteobacteria (Delftia) and members of the $\gamma$-proteobacteria. Although it is not possible to reliably correlate abundance of a particular sequence in clone libraries to abundance in a sample, $\gamma$-proteobacteria represented the highest percentage of clones in libraries generated with different bacterial primer sets (20-50\% depending on primer combination). Among the $17 \gamma$-proteobacterial sequences in our different 16S rRNA gene clone libraries, 16 were most closely related $(90 \%$ bootstrap support under maximum likelihood) to an uncultured Pseudomonas (AY987841), with its next closest relatives being Halomonas species and Marinobacter species (Figure 2). The $\gamma$-proteobacterial sequence affiliated with Pseudomonas is deposited in GenBank under the accession number JF414803.

\section{Functional gene sequencing}

The nitrite reductase gene nirK was also detected in DNA extracts from the SBB allogromiids. We recovered only one nirK sequence variant. The nirK sequence was most closely related to an uncultured bacteria (DQ182218) isolated from a denitrifying community in an activated sludge sample (Hallin et al., 2006), and also Mesorhizobium species 4FB11 based on phylogeny and BLAST analysis (data not shown). The single nirK sequence recovered was deposited in GenBank under the accession number JF414804. The nirS gene was not detected. Sulfur metabolism was not evident in the SBB allogromiid because (1) genes for sulfur oxidation $(\operatorname{sox} B)$ and sulfate reduction $(d s r A B)$ were not found, and (2) spectral and elemental maps did not indicate the presence of elemental $S$ in the endobionts aligning the large vacuole peripheries (data not shown).

\section{CARD-FISH}

DAPI staining and CARD-FISH with a universal eubacterial probe confirmed the presence of endobionts in our material (Figures 3a and b). CARDFISH with a general $\gamma$-proteobacterial probe was also positive (results not shown), whereas CARD-FISH using the general $\delta$ - and $\beta$-proteobacterial probes both produced negative results $(\sim 20$ allogromiids tested per probe, 3 separate hybridization trials), as were the NON probe (Figures $3 \mathrm{c}$ and $\mathrm{d}$ ) and allogromiids subject to the CARD-FISH procedure with no probe (both negative controls run on $\sim 20$ allogromiid cells each). Altogether, CARDFISH results suggested that the endobiont was a $\gamma$-proteobacterium. 

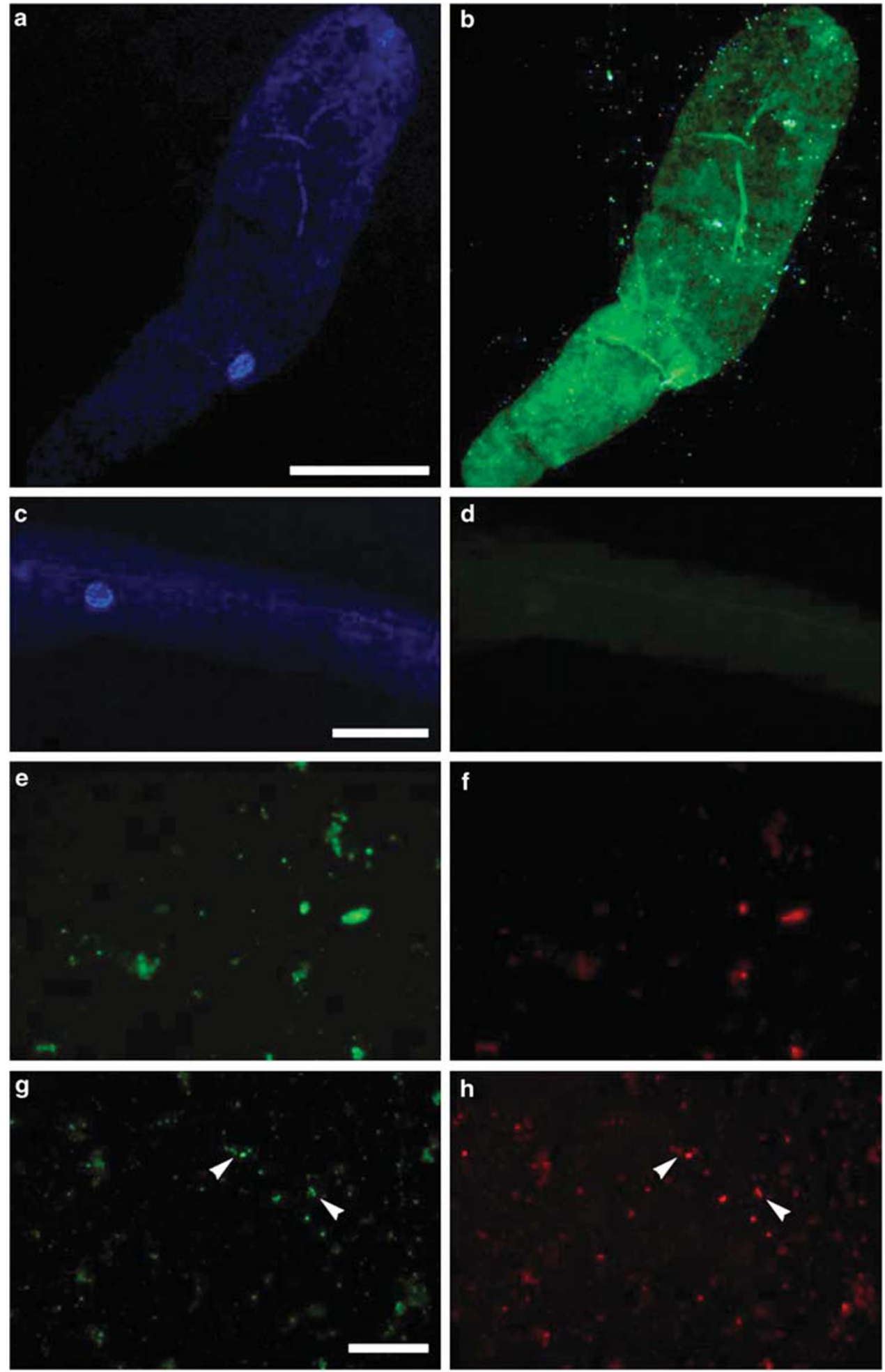

Figure 3 Paired FISH images of the SBB allogromiid. (a, b) Paired images of whole specimen showing DAPI (a) and DAPI/CARD-FISH with Cy3-labeled universal Eubacterial probe EUB338I-III (b). (c, d) Paired images of whole specimen showing DAPI (c) and CARD-FISH with Cy3-labeled negative control probe NON338 (d). (e, f) Paired GeneFISH images of lysed allogromiid hybridized to the FITC-labeled Pseudomonas-specific 16S rRNA gene probe (e) and negative control of Texas-Red labeled nirK gene (f) showing some non-specific background hybridization to cellular debris found in close association with some endobiont cells. (g, h) Paired GeneFISH images of another lysed allogromiid hybridized to the FITC-labeled Pseudomonas-specific 16S rRNA gene probe (g) and Texas-Red labeled nirK gene (h). Arrows indicate short chains of coccoid cells in FITC image (g) and coccoid cells in the GeneFISH image (h). Scales: a, $\mathbf{C}=50 \mu \mathrm{m} ; \mathbf{g}=20 \mu \mathrm{m}(\mathbf{e}-\mathbf{h}$ all same magnification) 


\section{FISH}

FISH using a fluorescein isothiocyanate (FITC)labeled general Pseudomonas probe and a published optimized protocol (Gunasekera et al., 2003) was positive (Figures 3e and f). Smear preparations of individual allogromiid cells provided clear images of the hybridization results with this probe, free of ambiguity caused by the faint background interference from the allogromiid (using optics for FITC/ Cy3). The exact percentage of endobiont cells that affiliate with the pseudomonads could not be calculated because we lacked sufficient allogromiid specimens to conduct a dual hybridization experiment using the universal bacterial probe and the Pseudomonas-specific probe. However, comparison of DAPI with FITC images of the same preparations, revealed only occasional $(<5 \%)$ endobiont cells that did not hybridize to both the $\gamma$-proteobacterial and Pseudomonas-specific FISH probes. As with CARDFISH, hybridizations with a NON probe and cells put through the same FISH procedure with no probe were both negative $(\sim 20$ SBB allogromiid cell preparations each).

\section{GeneFISH}

GeneFISH indicates that this nirK gene sequence is located within the endobionts (Figures $3 \mathrm{e}-\mathrm{h}$ ). A comparison of the signal for the gene probe labeled with Texas Red on the negative control filter (DNAsed filter, Figure 3f) to the same field of view under FITC showing hybridization of the 16S rRNA probe for Pseudomonas (Figure 3e), illustrates that there are very few false positives $(\sim 1 \%)$ with the nirK gene probe. For further explanation of the issues regarding false positives with the GeneFISH procedure, see the Materials and methods section. The low percentage of false positives was confirmed with a minimum of 10-15 fields of view on each of two different negative-control filters. When comparing the signal for the nirK gene probe on the positive filters (not DNAsed, for example, Figures $3 \mathrm{~g}$ and $\mathrm{h}$ ) with the signal on the negative controls (Figures 3e and f), a significant increase in signal was observed on the positive filters. The hybridization efficiency of the nirK gene probe (that is, percentage of positive cells for the nirK gene out of positive cells for the 16S rRNA gene) ranged from $\sim 50-65 \%$, depending on the filter and field of view (six filters observed, 10-15 fields per filter). This difference between the percentage of false positives and the percentage of true positives gives us confidence that the GeneFISH results are reliable.

\section{Discussion}

Intracellular nitrate contents and concentrations in the SBB allogromiid were high and comparable to those of other foraminifera reported to store nitrate and/or catalyze denitrification (Risgaard-Petersen et al., 2006; Høgslund et al., 2008; Piña-Ochoa et al., 2010). Thus, our inference that the abundant large cytoplasmic vacuoles (Figure 1a) are filled with nitrate is likely. High intracellular nitrate concentrations compared with surrounding waters (Sigman et al., 2003) suggest that the SBB allogromiid (and other foraminifera reported in the literature) are intentionally transporting $\mathrm{NO}_{3}^{-}$into their cells or are producing it intracellularly. Given that no known nitrifying microorganisms were detected in our clone libraries and that the allogromiids inhabit anoxic sediments (Bernhard et al., 2006), it is unlikely that $\mathrm{NO}_{3}^{-}$is being produced within the allogromiid cells. Instead, we hypothesize that $\mathrm{NO}_{3}^{-}$ is transported inside the foraminiferal cell for use by the endobionts. Although it was not a primary goal of this work, the $\delta^{15} \mathrm{~N}$ value of intracellular $\mathrm{NO}_{3}^{-}$was also determined for a subset of the individual allogromiids with sufficient intracellular $\mathrm{NO}_{3}^{-}$. The observed allogromiid $\delta^{15} \mathrm{~N}_{\mathrm{NO} 3}$ values were higher than for $\mathrm{NO}_{3}^{-}$in bottom water (8-12\%; Sigman et al. 2003), but should be compared with porewater $\delta^{15} \mathrm{~N}_{\mathrm{NO} 3}$ in order to determine whether $\mathrm{NO}_{3}^{-}$is fractionated during transport and/or consumption inside the cell. Unfortunately, porewater samples were not collected here, but remain an avenue of active research.

An earlier transmission electron microscopy study showed that the SBB allogromiids shows no evidence of ectobionts, but have endobionts of a single morphotype of coccoid to shortened rodshaped cells found as individuals or in short chains (Bernhard et al., 2006). Individual allogromiids, which are fragile and have a thin $(\sim 1 \mu \mathrm{m})$ test of clay particles (Bernhard et al., 2006), were difficult to completely clean of contaminating extracellular bacteria before nucleic acid isolation, even after rinsing specimens in several washes of sterile seawater. As a result, the obtained 16S rRNA gene clone libraries contained sequences from a variety of genotypes, most likely including some 'contaminating' bacteria. The washing procedures were sufficient, however, to remove a significant portion of contaminant bacteria from the surface of the tests, and similar to Bernhard et al. (2006), that used the same procedure; we only observed occasional, mostly filamentous external prokaryotes attached to the tests of this allogromiid during microscopy. Our attention was initially drawn to the $\gamma$-proteobacteria because they represented a significant portion of the recovered gene sequences (described above), which we infer to belong to the numerically dominant endobiont. Subsequent FISH experiments that showed positive hybridization with the general bacterial, general $\gamma$-proteobacterial and general Pseudomonas probes support the conclusion that the SBB allogromiid endobionts are pseudomonads. To our knowledge, these FISH results are the first ever reported in the literature for foraminiferal endobionts.

Marine pseudomonads capable of denitrification or nitrate reduction to ammonia are known (Gruntzig et al., 2001). Further, we recovered a single nirK 
sequence from the allogromiid, and by generating a probe unique to this nirK sequence were able to show with GeneFISH that this probe hybridized to the same endobiont cells that hybridized to the general Pseudomonas probe. The purpose of applying GeneFISH in this study was to determine whether the nirK gene sequence would localize to the endobionts or to the allogromiid host; we only observed hybridization to the endobionts. As noted above, although lysing individual allogromiid cells for the GeneFISH procedure destroys topological information, this process was required for an unambiguous interpretation of GeneFISH results due to interference from slight autofluorescence of the allogromiid in the FITC channels and from its 3-dimensional shape. Figures $3 e$ and $f$ show that the GeneFISH probe designed from our nirK sequence hybridizes to the same cells, as does the general Pseudomonas probe applied in this study. The connection between this nirK sequence and the specific Pseudomonas-related rRNA sequence recovered from the allogromiid is only indirect, as GeneFISH was not attempted with a 16S rRNA probe unique to the specific Pseudomonas-related rRNA sequence. However, we conclude that the allogromiid endobionts are likely a species of denitrifying pseudomonad because (1) nirK was detected in DNA extracts from the SBB allogromiid, (2) this nirK gene was localized to the endobionts and (3) the SBB allogromiid endobionts are spatially associated with the peripheries of vacuoles (Bernhard et al., 2006), which presumably contained the high observed concentrations of nitrate. The failure to detect genes for elemental sulfur oxidation and sulfate reduction is consistent with our conclusion in as much as Pseudomonas species are not recognized to carry out such sulfur metabolisms. Although the 16S rRNA gene sequence of the SBB allogromiid endobiont is most closely related to an uncultured Pseudomonas detected in a hypersaline saltern (Maturrano et al., 2006), the exact phylogenetic affiliation of this allogromiid endobiont within the Pseudomonadales should be interpreted with caution, until more sequences of uncultured pseudomonads are available in public databases.

Risgaard-Petersen et al. (2006) calculated that 6000-23000 denitrifying bacteria were necessary to account for the measured denitrification rates in their foraminiferal species. Using previously published transmission electron microscopy images crossing a transect of a SBB allogromiid, and average allogromiid length and width data presented in Bernhard et al. (2006) as well as average endobiont dimensions, we estimate the abundance of endobionts in an average SBB Clade L allogromiid to be $>250000$ bacteria, taking up $\sim 17.6 \%$ of the cell volume. Although we lack denitrification rates for the SBB allogromiid, the allogromiid endobiont abundance per foraminifer is 1-2 orders of magnitude greater than needed to account for denitrification rates reported for other foraminiferal species
(Risgaard-Petersen et al., 2006; Piña-Ochoa et al., 2010).

Denitrification is almost undoubtedly carried out by bacterial endobionts in this Clade L allogromiid species, even though no Clade L allogromiids have been shown to denitrify (nor tested for denitrification activity). Thus, our data suggests that denitrification in some species may be dominated by prokaryotic associates. Given that bacterial symbionts in benthic foraminiferal species from anoxic to micro-oxic habitats are not uncommon (Bernhard et al., 2000; Bernhard, 2003; Bernhard et al., 2010) and many or most of the foraminiferal species reported to denitrify (Piña-Ochoa et al., 2010) have not been examined for endo- and/or ectobionts, the role of prokaryotes in these associations deserves further study to resolve the enigma of foraminiferal denitrification. It is possible that other foraminiferal species, especially those lacking symbionts, may indeed perform complete denitrification but additional comparative studies using symbiont bearing and non-symbiont bearing species, as well as antibiotic treatments are required to shed more light on the ability of these eukaryotes to denitrify.

The activity of the endobionts apparently allows the host to survive in anoxic habitats. The mechanism of this interaction is currently unknown, but may occur through removal of hydrogen or other metabolic intermediates. From a different perspective, non-fossilizable unilocular foraminifera similar to the SBB allogromiid evolved before more commonly known multilocular calcareous forms; such evolution likely occurred in the Neoproterozoic era (Pawlowski et al., 2003). Convincing evidence exists suggesting that anoxic marine habitats were extensive at this time (Frei et al., 2009). Thus, acquisition of denitrifying bacterial symbionts would have expanded the foraminiferal habitat range early in their history.

\section{Acknowledgements}

We thank the captain and crew of the RV Robert Gordon Sproul, all science party members for their help with sampling, Joe DeGiorgis for early attempts to identify vacuole contents, Sam Bowser and Amanda Andreas for assistance with elemental mapping, Edward Leadbetter for insights on bacterial metabolism and three anonymous reviewers for helpful comments on an earlier manuscript version. This research was supported by NSF Grant EF0702491 to JMB, KLC and VPE; some ship support was provided by NSF Grant MCB-0604084 to VPE and JMB.

\section{References}

Amann RI, Binder BJ, Olson RJ, Chisholm SW, Devereux R, Stahl DA. (1990). Combination of $16 \mathrm{~S}$ ribosomalRNA-targeted oligonucleotide probes with flow 
cytometry for analyzing mixed microbial populations. Appl Environ Microbiol 56: 1919-1925.

Bernhard JM. (2003). Potential symbionts in bathyal foraminifera. Science 299: 861-861.

Bernhard JM, Buck KR, Farmer MA, Bowser SS. (2000). The Santa Barbara Basin is a symbiosis oasis. Nature 403: $77-80$.

Bernhard JM, Goldstein ST, Bowser SS. (2010). An ectobiont-bearing foraminiferan, Bolivina pacifica, that inhabits microxic pore waters: cell-biological and paleoceanographic insights. Environ Microbiol 12: $2107-2119$.

Bernhard JM, Habura A, Bowser SS. (2006). An endobiontbearing allogromiid from the Santa Barbara Basin: implications for the early diversification of foraminifera. J Geophys Res-Biogeosciences 111: G03002, doi:10.1029/2005JG000158.

Bernhard JM, Sen Gupta BK, Borne PF. (1997). Benthic foraminiferal proxy to estimate dysoxic bottom-water oxygen concentrations: Santa Barbara basin, US Pacific continental margin. J Foramin Res 27: 301-310.

Bernhard JM, Visscher PT, Bowser SS. (2003). Submillimeter life positions of bacteria, protists, and metazoans in laminated sediments of the Santa Barbara Basin. Limnol Oceanogr 48: 813-828.

Braker G, Fesefeldt A, Witzel KP. (1998). Development of PCR primer systems for amplification of nitrite reductase genes (nirK and nirS) to detect denitrifying bacteria in environmental samples. Appl Environ Microbiol 64: 3769-3775.

Casciotti KL, Ward BB. (2001). Dissimilatory nitrite reductase genes from autotrophic ammonia-oxidizing bacteria. Appl Environ Microbiol 67: 2213-2221.

Cole JR, Chai B, Marsh TL, Farris RJ, Wang Q, Kulam SA et al. (2003). The Ribosomal Database Project (RDP-II): previewing a new autoaligner that allows regular updates and the new prokaryotic taxonomy. Nucleic Acids Res 31: 442-443.

Daims H, Bruhl A, Amann R, Schleifer KH, Wagner M. (1999). The domain-specific probe EUB338 is insufficient for the detection of all Bacteria: development and evaluation of a more comprehensive probe set. Syst Appl Microbiol 22: 434-444.

Dalsgaard T, Thamdrup B, Canfield DE. (2005). Anaerobic ammonium oxidation (anammox) in the marine environment. Res Microbiol 156: 457-464.

Edgcomb VP, Breglia SA, Yubuki N, Beaudoin DJ, Patterson DJ, Leander BS et al. (2010). Identity of epibiotic bacteria on symbiontid euglenozoans in $\mathrm{O}_{2}$ depleted marine sediments: evidence for symbiont and host co-evolution. ISME J 5: 231-243.

Francis CA, Beman JM, Kuypers MMM. (2007). New processes and players in the nitrogen cycle: the microbial ecology of anaerobic and archaeal ammonia oxidation. ISME J 1: 19-27.

Frei R, Gaucher C, Poulton SW, Canfield DE. (2009). Fluctuations in Precambrian atmospheric oxygenation recorded by chromium isotopes. Nature 461: 250-U125.

Gruntzig V, Nold SC, Zhou JZ, Tiedje JM. (2001). Pseudomonas stutzeri nitrite reductase gene abundance in environmental samples measured by real-time PCR. Appl Environ Microbiol 67: 760-768.

Gunasekera TS, Dorsch MR, Slade MB, Veal DA. (2003). Specific detection of Pseudomonas spp. in milk by fluorescence in situ hybridization using ribosomal RNA directed probes. J Appl Microbiol 94: 936-945.
Hallin S, Lindgren PE. (1999). PCR detection of genes encoding nitrile reductase in denitrifying bacteria. Appl Environ Microbiol 65: 1652-1657.

Hallin S, Throback IN, Dicksved J, Pell M. (2006). Metabolic profiles and genetic diversity of denitrifying communities in activated sludge after addition of methanol or ethanol. Appl Environ Microbiol 72: $5445-5452$.

Høgslund S, Revsbech NP, Cedhagen T, Nielsen LP, Gallardo VA. (2008). Denitrification, nitrate turnover, and aerobic respiration by benthic foraminiferans in the oxygen minimum zone off Chile. J Exp Mar Biol Ecol 359: 85-91.

Könneke M, Bernhard AE, de la Torre JR, Walker CB, Waterbury JB, Stahl DA. (2005). Isolation of an autotrophic ammonia-oxidizing marine archaeon. Nature 437: 543-546.

Lane D (ed.). (1991). 16S/23S rRNA sequencing. John Wiley \& Sons: New York, pp 115-175.

Longnecker K, Reysenbach AL. (2001). Expansion of the geographic distribution of a novel lineage of epsilonProteobacteria to a hydrothermal vent site on the Southern East Pacific Rise. FEMS Microbiol Ecol 35: 287-293.

Loy A, Kusel K, Lehner A, Drake HL, Wagner M. (2004). Microarray and functional gene analyses of sulfatereducing prokaryotes in low-sulfate, acidic fens reveal cooccurrence of recognized genera and novel lineages. Appl Environ Microbiol 70: 6998-7009.

Lucker S, Steger D, Kjeldsen KU, MacGregor BJ, Wagner M, Loy A. (2007). Improved 16S rRNA-targeted probe set for analysis of sulfate-reducing bacteria by fluorescence in situ hybridization. J Microbiol Methods 69: 523-528.

Ludwig W, Strunk O, Westram R, Richter L, Meier H, Yadhukumar et al. (2004). ARB: a software environment for sequence data. Nucleic Acids Res 32: 1363-1371.

Manz W, Amann R, Ludwig W, Wagner M, Schleifer K-H. (1992). Phylogenetic oligodeoxynucleotide probes for the major subclasses of proteobacteria-problems and solutions. Syst Appl Microbiol 15: 539-600.

Maturrano L, Santos F, Rossello-Mora R, Anton J. (2006). Microbial diversity in Maras salterns, a hypersaline environment in the Peruvian Andes. Appl Environ Microbiol 72: 3887-3895.

Michotey V, Mejean V, Bonin P. (2000). Comparison of methods for quantification of cytochrome cd(1)-denitrifying bacteria in environmental marine samples. Appl Environ Microbiol 66: 1564-1571.

Moraru C, Lam P, Fuchs BM, Kuypers MMM, Amann R. (2010). GeneFISH-an in situ technique for linking gene presence and cell identity in environmental microorganisms. Environ Microbiol 12: 3057-3073.

Muyzer G, Dewaal EC, Uitterlinden AG. (1993). Profiling of complex microbial populations by denaturing gradient gel electrophoresis analysis of polymerase chain reaction-amplified genes coding for $16 \mathrm{~S}$ robosomal RNA. Appl Environ Microbiol 59: 695-700.

Pawlowski J, Holzmann M, Berney C, Fahrni J, Gooday AJ, Cedhagen T et al. (2003). The evolution of early Foraminifera. Proc Natl Acad Sci USA 100: 11494-11498.

Pernthaler A, Pernthaler J, Amann R. (2002). Fluorescence in situ hybridization and catalyzed reporter deposition for the identification of marine bacteria. Appl Environ Microbiol 68: 3094-3101. 
Pernthaler J, Glockner FO, Schonhuber W, Amann R (eds). (2001). Fluorescence in situ hybridization (FISH) with rRNA-targeted oligonucleotide probes. Academic Press: San Deigo, pp. 207-226.

Petri R, Podgorsek L, Imhoff JF. (2001). Phylogeny and distribution of the $\operatorname{sox} B$ gene among thiosulfate-oxidizing bacteria. FEMS Microbiol Letters 197: 171-178.

Piña-Ochoa E, Høgslund S, Geslin E, Cedhagen T, Revsbech NP, Nielsen LP et al. (2010). Widespread occurrence of nitrate storage and denitrification among Foraminifera and Gromiida. Proc Natl Acad Sci USA 107: 1148-1153.

Reimers CE, Lange CB, Tabak M, Bernhard JM. (1990). Seasonal spillover and varve formantion in the Santa Barbara Basin, California. Limnol Oceanogr 35: 1577-1585.

Reimers CE, Ruttenberg KC, Canfield DE, Christiansen MB, Martin JB. (1996). Porewater $\mathrm{pH}$ and authigenic phases formed in the uppermost sediments of the Santa Barbara Basin. Geochim Cosmochim Acta 60: 4037-4057.

Reysenbach AL, Pace NR (eds). (1994). Reliable amplification of hyperthermophilic Archaeal 16S rRNA genes by the polymerase chain reaction. Cold Spring Harbor Laboratroy Press: Cold Spring Harbor.

Risgaard-Petersen N, Langezaal AM, Ingvardsen S, Schmid MC, Jetten MSM, Op den Camp HJM et al. (2006). Evidence for complete denitrification in a benthic foraminifer. Nature 443: 93-96.

Sigman DM, Casciotti KL, Andreani M, Barford C, Galanter M, Bohlke JK. (2001). A bacterial method for the nitrogen isotopic analysis of nitrate in seawater and freshwater. Anal Chem 73: 4145-4153.
Sigman DM, Robinson R, Knapp AN, van Geen A, McCorkle DC, Brandes JA et al. (2003). Distinguishing between water column and sedimentary denitrification in the Santa Barbara Basin using the stable isotopes of nitrate. Geochem Geophys Geosyst 4.

Stahl DA, Amann R (eds). (1991). Development and application of nucleic acid probes in bacterial systematics. Wiley \& Sons Ltd: Chichester, England, pp 205-248.

Stamatakis A. (2006). RAxML-VI-HPC: maximum likelihood-based phylogenetic analyses with thousands of taxa and mixed models. Bioinformatics 22: 2688-2690.

Stamatakis A, Hoover P, Rougemont J. (2008). A rapid bootstrap algorithm for the RAxML web servers. Syst Biol 57: 758-771.

Throback IN, Enwall K, Jarvis A, Hallin S. (2004). Reassessing PCR primers targeting nirS, nirK and nosZ genes for community surveys of denitrifying bacteria with DGGE. FEMS Microbiol Ecol 49: 401-417.

Wallner G, Amman RI, Beisker W. (1993). Optimizing fluorescent in situ hybridization with rRNAtargeted oligonucleotide probes for flow cytometric identification of microorganisms. Cytometry 14: 136-143.

Winnepenninckx B, Backeljau T, Dewachter R. (1993). Extraction of high molecular weight NDA from mollusks. Trends Genet 9: 407-407.

Yeates C, Saunders AM, Crocetti GR, Blackall LL. (2003). Limitations of the widely used GAM42a and BET42a probes targeting bacteria in the Gammaproteobacteria radiation. Microbiology 149: 1239-1247. 